\title{
The Role of Playing Model Learning Based on Tri Hita Karana Improve Indonesian Language Learning Outcomes
}

\author{
Komang Trisnawati \\ Program Studi Pendidikan Guru Sekolah Dasar, FIP, Universitas Pendidikan Ganesha, Singaraja, Indonesia \\ Email: Komangtrisnawati14@gmail.com
}

I Wayan Ilia Yuda Sukmana

Program Studi Teknologi Pendidikan, FIP, Universitas Pendidikan Ganesha, Singaraja, Indonesia Email: yudasukmanatp@gmail.com

\section{A R T I C L E I N F O \\ Article history: \\ 1 Mei 2020 Received in revised form \\ 11 Juni 2020 \\ Accepted 10 Juli 2020 \\ Available online 25 Agustus 2020 \\ Kata Kunci: \\ Role Playing, Tri Hita \\ Karana, Hasil Belajar}

\section{Keywords:}

Role Playing, Tri Hita

Karana, Learning

Outcomes

\begin{abstract}
A B S T R A K
Dilaksanakannya penelitian ini berdasarkan atas pemasalahan-permasalahan yang ditemukan pada saat observasi, yaitu sulitnya siswa belajar khususnya dalam pembelajaran IPA yang berdampak terhadap hasil belajar siswa dan pembelajaran yang masih bersifat teacher centered yang menyebabkan siswa menjadi pasif. berdasarkan permasalahan tersebut, maka penelitian ini bertujuan untuk menganalisis efektivitas model Two Stay Two Stray berbantuan mind mapping terhadap hasil belajar IPA siswa. Jenis penelitian ini ialah eksperimen semu dengan desain Nonequivalent Control Group Design. Rancangan penelitisn yang digunakan yaitu post-test only control group design. Populasi pada penelitian ini berjumlah 147 siswa yang terdiri atas empat kelas. Penentuan sampel dilakukan dengan cara random sampling berupa pengundian. Jumlah sampel sebanyak 72 siswa, yaitu kelas eksperimen berjumlah 36 siswa dan kelas kontrol berjumlah 36 siswa. Pengumpulan data post-test dilakukan dengan metode tes yang berjenis objektif pilihan ganda. Kemudian, dilakukan analisis dengan rumus uji-t. Dari hasil analisis, ditunjukkan bahwa didapatkan thitung $=3,920>t_{\text {tabel }}=1,99444$. Berdasarkan hasil tersebut, terdapat perbedaan hasil belajar IPA yang signifikan antara kelas yang diberikan perlakuan model pembelajaran TSTS berbantuan metode mind mapping dengan kelas yang diberikan perlakuan model pembelajaran konvensional. Hasil dari perhitungan didapat kelas eksperimen memiliki mean yang lebih tinggi daripada kelas kontrol, yaitu
\end{abstract} 79,06>68,75. Berdasarkan hal tersebut, maka model pembelajaran TSTS berbantuan metode mind mapping efektif terhadap hasil belajar IPA siswa.

\begin{abstract}
A B S T R A C T
This study aimed to determine the effect of the Tri Hita Karana based Role Playing type of cooperative learning model on Indonesian language learning outcomes. This study was a quasi-experimental study with a non-equivalent post-test only control group design. The population of this study was 177 people, the sample was determined using simple random sampling. Indonesian learning outcomes data was obtained through the method of providing multiple-choice tests. Based on the results of hypothesis testing, it showed that there was significant difference in Indonesian learning outcomes between groups of students who were taught with a cooperative learning model based on Tri Hita Karana type and students who were not taught using the cooperative learning model based on Tri Hita Karana. Thus, the cooperative learning model of Role Playing based on Tri Hita Karana affects the learning outcomes in Indonesian students. Based on the results of the study, it is recommended that this study can be used as a support or relevant study in subsequent studies to fund a type of cooperative learning model based on Tri Hita Karana.
\end{abstract}

\section{Introduction}

The 2013 curriculum carries the concept of integrated thematic learning. In integrated thematic learning, there are several content lessons, one of them is Indonesian. Indonesian is the main subject in the curriculum that applies to Indonesia, both KTSP (2006 curriculum) and the 2013 curriculum. Indonesian learning always exists at every level of education, it is because the main purpose of learning a language can develop students' intellectual and emotional as well as support the success in learning other lessons. Language is humans' ability to communicate with others. (Rosdiana, 2014) states that language is a system of arbitrary sound-symbols used by all people and social groups to work together, communicate to identify themselves. In line with the explanation above, language is a formed system from several components that are patterned permanently and can be addressed. The language system is in the form of sound-symbols, each language symbol symbolizes something called as meaning or concept. Because each sound-symbol has or states a concept or meaning, it can be concluded that every language 
utterance has meaning (Abdul \& Agustina, 2004). Humans always interact, communicate with other humans using language as a medium, both communicating using spoken language and written language (Susanto, 2013). Indonesian is very important to be mastered in life because it has a function to interact with other people, express conveyed feelings or ideas and it is used to develop one's abilities (Dibia et al., 2017).

Indonesian at the elementary school level has the aim to use the literature in gaining broad insights and develop language skills. Language Learning in Elementary Schools essentially gives habits and develops students' abilities from the early age so they can communicate properly and correctly as well as students have a desire to read, hone skills in the field of art or literature to improve personality, sharpen sensitivity, feelings, and broaden horizons (Sumayasa et al., 2015; Susanto, 2013). Indonesian learning is always bound by four aspects of language, namely listening, speaking, reading, and writing. Listening skills cannot be separated from the ability to speak, read, and write. Listening skill is an important language skills and must be taught at the earliest before other language skills, where one's success in listening can be seen from how listeners understand and convey information from listening orally or in writing. Therefore, listening is important in the learning process to understand the material being taught, if students do not listen well, it will affect learning outcomes. Therefore, it is expected that teachers create a pleasant learning atmosphere in Indonesian learning process so students' attention is focused on learning and teachers must provide opportunities for students to increase their language experience.

However, in reality, the expected learning process in Indonesian language content does not match the reality. It was revealed from the results of interviews, observations, and documentation at SD (Elementary School) in Cluster XIII, Buleleng District, related to student learning outcomes under KKM (minimum completeness criteria) on Indonesian subject matter. When an interview was conducted with the fourth grade homeroom teacher, on $19^{\text {th }}$ to $22^{\text {nd }}$ October 2019 at SD cluster XIII, Buleleng District, the fouth grade homeroom teacher said that students lacked enthusiasm for learning such as finding out the answers to the questions asked by the teacher during Indonesian learning process. After conducting the interview, it was continued with the observation activities in Indonesian language learning process for the fouth grade of elementary school in cluster XIII, Buleleng District. When conducting the observations, it was seen that the student's participation was low in asking, answering, and giving opinions in the learning process; and students could not explain the material that had been learned again, the students did not understand the material because the students could not answer the question given by teacher. It is because when the learning process takes place, students do not pay attention to the teacher and they tend to chat with their peers. Thus, it can be said that students do not listen to the material presented by the teacher.

Completing the results of the interviews and observations, it is followed by a study of the Indonesian test scores for the odd semester of the fourth grade Elementary School in Cluster XIII, Buleleng District, academic year 2019/2020. The results in Indonesian middle test can be seen in Table 1.

Table 1. The Result in Indonesian Middle Test of the Fourth Grade

\begin{tabular}{lcccccc}
\hline Elementary School & Class & $\begin{array}{c}\text { Number } \\
\text { of } \\
\text { Students }\end{array}$ & Average & $\begin{array}{c}\text { KKM } \\
\text { (minimum } \\
\text { completeness } \\
\text { criteria) }\end{array}$ & $\begin{array}{c}\text { Number } \\
\text { of } \\
\text { students } \\
\text { who pass } \\
\text { KKM }\end{array}$ & $\begin{array}{c}\text { Number of } \\
\text { students } \\
\text { who do not } \\
\text { pass KKM }\end{array}$ \\
\hline SD Negeri 1 Banjar Tegal & IV & 28 & 59.52 & 70 & 7 & 21 \\
SD Negeri 2 Banjar Tegal & IV & 25 & 61.12 & 75 & 4 & 21 \\
SD Negeri 3 Banjar Tegal & IV & 8 & 55 & 67 & 2 & 6 \\
SD Negeri 1 Baktiseraga & IV A & 28 & 60.21 & 75 & 0 & 28 \\
SD Mutiara & IV B & 32 & 52.41 & & 0 & 32 \\
& IV A & 29 & 61.72 & 75 & 6 & 23 \\
\hline
\end{tabular}

Based on Table 1, the number of the fourth grade elementary school students in cluster XIII, Buleleng District, was 177 students, it can be seen that there were still 152 students who got Indonesian learning outcomes under the predetermined KKM. It becomes a problem that must be resolved to improve the learning outcomes in Indonesian of the fourth grade elementary school students in cluster XIII, Buleleng District. Therefore, to overcome these problems, the teacher must create an attractive learning atmosphere through the implementation of learning models to build student participation in a group during learning process and improve student learning outcomes.

The learning model is a series of learning activities conducted by students in a small group to achieve learning objectives. According to (Rosyidah, 2016), the learning model is a learning process that involves students working and interacting with their friends. In line with it, Sunarwan in (Sutikno, 2004), states that the learning 
model or teaching model is a plan or pattern used in organizing subject matter and giving instructions on how to teach in class in a teaching-learning setting. One of the learning models that can be applied is the Role Playing learning model. The Role Playing learning model is a group learning model that makes it easier for students to interact with their social environment (Sari, 2018; Mushfi, 2017). Role playing learning model is a learning process by playing a role play that contains pleasant goals, rules, and elements in conducting the learning process and can attract students' attention, they can play roles as characters in an event. This learning model is suitable for learning materials that involve real life problem situations (Dewi, 2017). This statement is supported by (Santoso, 2011) who states that the role playing model is a way of mastering learning materials through developing the imagination and appreciation of students in which there are pleasant rules, objectives, and elements in conducting teaching and learning process. From the explanation above, it can be concluded that the Role Playing learning model is a learning activity involving groups to learn through games so that students can develop their imagination and express feelings through role playing. Thus, the implementation of role playing learning can create a pleasant learning atmosphere so students easily understand the material through games. In the learning model, Role Playing has characteristics. (Susanty, 2017) states that the Role Playing model has 5 characteristics as follows: first, the Role Playing learning model is a fun learning process and has positive values for children in participating the learning; the second, learning process generates intrinsic motivation so the students can conduct these activities of their accord; the third, the nature are spontaneous and voluntary, students will feel free to choose or use as an alternative for their play activities; the fourth, it creates student activity and participation; the fifth, it arouse students' creative abilities, language skills, problem solving, and abilities make friends as many as possible. Considering the characteristics above, the Role Playing learning model will arouse students' enthusiasm for the learning process so that students easily understand the material. Role playing can be used to stimulate students' opinions and find mutual agreement about the accuracy, shortcomings, and development of roles that they experience or observe (Adiwiguna et al., 2016).

In implementing the Role Playing learning model, the role of the teacher is very important to create a harmonious relationship between students so that the learning process creates a comfortable, peaceful, and peaceful sense of life. Therefore, students need to know Tri Hita Karana in the learning process. Tri Hita Karana in Hinduism is about how to maintain a harmonious relationship between God, living things, and the environment so that happiness can be created in life. The concept of Tri Hita Karana teaches humans to always maintain harmony in the world starting from themselves and everything around them (Pradnyawathi \& Agustika, 2019). According to (Krishna, 2018), Tri Hita Karana is a concept of local wisdom or spiritual concept that originates from Indonesian local culture and it is still known today in Bali Island. In line with the explanation above, the essence of the tri hita karana according to (Wiana, 2004) emphasizes three human relationships in life in this world. The three relationships include relationships among humans, relationships with the natural surroundings, and relationships with God that are interrelated with one another. Etymologically, the Sanskrit term of Tri Hita Karana comes from the words Tri, Hita, and Karana. Tri means three, Hita means happy, and Karana means cause. Three elements of life regulate balance or harmony, namely Parhyangan (human relations with Ida Sang Hyang Widhi Wasa (God)), Palemahan (human relations with the surrounding environment), and Pawongan (human-human relations) (Jaya, 2019; Widyaswari, 2019). The value of Tri Hita Karana can be instilled in students which influences the students' behavior (Astami, et al. 2016). Thus, the application of the Role Playing model combined with the Tri Hita Karana will be a breakthrough in presenting learning, especially in Indonesian content.

From the description above, it is supported by the results of a study conducted by (Basri, 2017) states that students' activeness in learning tends to increase at each meeting, the students' activity is an increase from the number of students who pay attention to the teacher in applying Role Playing model so that it can improve learning results in Indonesian both individually and classically. In addition, it is supported by the result of a study conducted by (Narayani et al., 2019) which reveals that students are more enthusiastic in learning with Tri Hita Karana, students are accustomed to protect the environment in creating a conducive learning environment and improve students character.

Based on the description above, it is believed that the Tri Hita Karana based Role Playing learning model can create an active learning process so that it can improve student learning outcomes, especially Indonesian content. To study more deeply, the purpose of this study was to determine the effect of the Tri Hita Karana based Role Playing learning model on Indonesian learning outcomes of the fourth grade elementary school students in Cluster XIII, Buleleng District, academic year 2019/2020.

\section{Method}


This study was a quasi experiment. The design of this study applied a non-equivalent post-test only control group design. In this design, two groups were used, namely the experimental group and the control group. The experimental group was a group that was treated by applying the Tri Hita Karana based Role Playing learning model, while the control group was not treated by applying the Tri Hita Karana based Role Playing learning model.

The population of the study was all the fourth grade elementary school students in Cluster XIII, Buleleng District, from 177 students. In this study, random sampling technique was used to select the samples. From the random results, the selected elementary schools were SD Negeri 1 Banjar Tegal and SD Negeri 1 Baktiseraga. The specified samples were the fourth grade students in SD Negeri 1 Banjar Tegal with total students of 28 as the experimental group and the fourth grade in SD Negeri 1 Baktiseraga with total students of 28 as the control group. The experimental group was treated with Tri Hita Karana based Role Playing learning model, while the control group was not given the Tri Hita Karana based Role Playing learning model.

The collected data in this study were the results of learning Indonesian in the listening aspect of the cognitive realm of the fourth grade students which was the dependent variable. In this study, the post-test was a multiple-choice test with 20 items. The post-test was based on Revised Bloom's Taxonomy at the C1 to C4 levels (remembering, understanding, applying, and analyzing). The post-test focused on theme 6 sub-theme 1 which was about poetry of the fourth grade. Previously, the post-test is tested for validity, reliability, difficulty level, and different power. After testing it, it is ready to be given to the experimental group and control group. The obtained post-test data were then analyzed by descriptive and inferential analysis.

The results of post-test were analyzed to answer the hypothesis in this study. The hypothesis test in this study applied the t-test of the Independent Samples Test with polled variance formula assisted by SPSS-17.0. However, before testing the hypothesis, the analysis prerequisite test was conducted firstly consisting of the normality test using the Kolmogorov-Smirnov, Shapiro-Wilk techniques, and the homogeneity test. Data can be said to be normally distributed if the significance is greater than 5\% or 0.05 (Agung, 2016). After the data was normally distributed and homogeneous, it was continued with hypothesis testing using the t-test to find out whether there was an effect of the Tri Hita Karana based Role Playing learning model on the Indonesian learning outcomes of the fourth grade elementary school students in cluster XIII, Buleleng District, academic year 2019/2020.

\section{Result and Discussion}

Based on the data collection, the results of the post-test descriptive statistical analysis on Indonesian in the experimental class and control class of the fourth grade elementary school students were presented in Table 2.

Table 2. The Description Summary of Indonesian Post-test Result

\begin{tabular}{lcc}
\hline \multicolumn{1}{c}{ Data Description } & Experimental Group & Control Group \\
\hline Mean & 15,78 & 12,78 \\
Median & 16 & 13 \\
Mode & 17 & 13 \\
Standard Deviation & 1,6 & 1,6 \\
Variance & 2,56 & 2,56 \\
\hline
\end{tabular}

Based on Table 2, the results of the descriptive analysis showed that the experimental group average score was higher than the control group $15.78>12.78$, the experimental group median was higher than the control $16>$ 13, the mode of the experimental group was higher than the control group $17>13$, the standard deviation of the experimental group was the same as the control group, namely 1.6, and the variance of the experimental group was also 2.56 as same as the control.

Furthermore, the post-test data of the experimental group and the control group were analyzed using the normality and homogeneity test. Normality testing applied the Kolmogorov-Smirnov and Shapiro-Wilk technique and homogeneity test with Levene's Test of Equality of Error Variance assisted SPSS 17.0. Normality and homogeneity tests were conducted with a significance criterion greater than $0.05(5 \%)$ so it can be categorized as normal and homogeneous. The results of the normality test analysis using the Kolmogorov-Smirnov and ShapiroWilk technique can be seen in Table 3 .

Table 3. The Result of Normality Test with Kolmogorov-Sirnov and Shapiro-Wilk 


\begin{tabular}{llcccccc}
\hline & \multirow{2}{*}{ Group } & \multicolumn{3}{c}{ Kolmogorov-Smirnov ${ }^{\text {a }}$} & \multicolumn{3}{c}{ Shapiro-Wilk } \\
\cline { 3 - 8 } & & Statistic & Df & Sig. & Statistic & Df & Sig. \\
\hline Learning & Experimental & .145 & 28 & .135 & .964 & 28 & .421 \\
outcome & Control & .161 & 28 & .062 & .953 & 28 & .235 \\
\hline \multicolumn{9}{c}{} \\
\hline
\end{tabular}

Based on the calculation results of Table 3, it showed that in the experimental group the significant value in the Kolmogorov-Smirnov column obtained a price of 0.135 and the Shapiro-Wilk column obtained a price of 0.421 . Whereas in the control group, the Kolmogorov-Smirnov column obtained a price of 0.062 and in the Shapiro-Wilk column the price was 0.235 . It means that the significant value in the experimental and control groups is greater than 0.05 . Thus, it can be concluded that the research data is normally distributed.

Furthermore, the variance homogeneity test was conducted. The variance homogeneity test was conducted to find out the data from the same variance. The variance homogeneity test of the two data groups used the Levene's Test of Equality of Error Variance assisted by SPSS 17.0 for Windows. The following were the analysis result of variance homogeneity using Levene's Test of Equality of Error Variance.

Table 4. The Result of Variance Homegenity Test of Experimental and Control Group

\begin{tabular}{|c|c|c|c|c|c|}
\hline \multicolumn{6}{|c|}{ Test of Variance Homogeneity } \\
\hline & & Levene Statistic & df1 & df2 & Sig. \\
\hline \multirow{4}{*}{$\begin{array}{l}\text { Indonesian } \\
\text { learning } \\
\text { outcome }\end{array}$} & Based on Mean & .004 & 1 & 54 & .949 \\
\hline & Based on Median & .000 & 1 & 54 & 1.000 \\
\hline & $\begin{array}{l}\text { Based on Median and } \\
\text { with adjusted df }\end{array}$ & .000 & 1 & 53.275 & 1.000 \\
\hline & $\begin{array}{l}\text { Based on tremmed } \\
\text { mean }\end{array}$ & .013 & 1 & 54 & .911 \\
\hline
\end{tabular}

Based on Table 4, the significant value in Mean column showed a price of 0.949 . These results indicate that the significant value is greater than 0.05 or $0.949>0.05$ so it can be concluded that the research data is declared homogeneous.

After conducting the prerequisite analysis, it was continued with testing the research hypothesis with the ttest using the Independent Samples Test with polled variance assisted by SPSS-17.0 for windows. Hypothesis testing criteria with the results of t-test calculations using the Independent Samples Test assisted by SPSS 17.0 for Windows are presented in Table 5.

Table 5. The Result of Hypothesis Test in Indonesian Learning Outcome

Independent Samples Test

\begin{tabular}{|c|c|c|c|c|c|c|c|c|c|c|}
\hline & & $\begin{array}{c}\text { Lev } \\
\text { Tes } \\
\text { Equ } \\
\text { Var }\end{array}$ & $\begin{array}{l}\text { ne's } \\
\text { for } \\
\text { lity } \\
\text { nces }\end{array}$ & \multicolumn{7}{|c|}{ t-test for Equality of Means } \\
\hline & & & & & & & & & \multicolumn{2}{|c|}{$\begin{array}{c}95 \% \text { Confidence } \\
\text { Interval of the } \\
\text { Difference } \\
\end{array}$} \\
\hline & & $\mathbf{F}$ & Sig. & $\mathbf{T}$ & Df & $\begin{array}{c}\text { Sig. } \\
(2- \\
\text { tailed } \\
)\end{array}$ & $\begin{array}{c}\text { Mean } \\
\text { Differenc } \\
\mathbf{e}\end{array}$ & $\begin{array}{c}\text { Std. } \\
\text { Error } \\
\text { Differenc } \\
\text { e }\end{array}$ & Lower & Upper \\
\hline \multirow{2}{*}{$\begin{array}{l}\text { Indonesi } \\
\text { an } \\
\text { learning } \\
\text { outcome }\end{array}$} & $\begin{array}{l}\text { Equal } \\
\text { variances } \\
\text { assumed }\end{array}$ & $\begin{array}{c}.00 \\
4\end{array}$ & $\begin{array}{c}.94 \\
9\end{array}$ & $\begin{array}{c}7.19 \\
5\end{array}$ & 54 & .000 & 3.00000 & .41695 & $\begin{array}{c}2.1640 \\
7\end{array}$ & $\begin{array}{c}3.8359 \\
3\end{array}$ \\
\hline & $\begin{array}{l}\text { variances } \\
\text { not } \\
\text { assumed }\end{array}$ & & & $\begin{array}{c}7.19 \\
5\end{array}$ & $\begin{array}{c}53.88 \\
8\end{array}$ & .000 & 3.00000 & .41695 & $\begin{array}{c}2.1640 \\
3\end{array}$ & $\begin{array}{c}3.8359 \\
7\end{array}$ \\
\hline
\end{tabular}

From Table 5, it can be concluded that the results of the hypothesis test with the t-test Independent Samples Test show that the significant value in the sig (2-tailed) column is 0.000 . This significant value is smaller than 0.05 
so that $\mathrm{H}_{\mathrm{o}}$ is rejected and $\mathrm{H}_{1}$ is accepted. These results state that there is an effect of the Tri Hita Karana based Role Playing learning model on the Indonesian learning outcomes of the fourth grade elementary school students in Cluster XIII, Buleleng District, academic year 2019/2020.

The implementation of the Tri Hita Karana based Role Playing learning model has a significant effect on the learning outcomes in Indonesian of the fourth grade elementary school students in Cluster XIII, Buleleng District, academic year 2019/2020. It can be seen from the difference in the average score in Indonesian learning outcomes between the experimental groups that was taught with the Tri Hita Karana based Role Playing learning model and the control group that was not taught with the Tri Hita Karana based Role Playing learning model. The experimental group obtained an average learning outcome score of 15.78 while the control group obtained an average learning outcome score of 12.78. When they are compared, it is known that $15.78>12.78$ so that it can be said that the Tri Hita Karana based Role Playing learning model has a positive influence on the results of learning Indonesian of the fourth grade elementary school students in cluster XIII, Buleleng District. Furthermore, from the results of the t-test, it is known that the significant value is smaller than 0.05 so that $\mathrm{H}_{\mathrm{o}}$ is rejected and $\mathrm{H}_{1}$ is accepted. These results state that there is an effect of the Tri Hita Karana based Role Playing learning model on the Indonesian language learning outcomes of the fourth grade elementary school students in Cluster XIII, Buleleng District, academic year 2019/2020

There is a difference in Indonesian learning outcomes between students who were taught with Tri Hita Karana based Role Playing and students who were not taught with Tri Hita Karana based Role playing. It is because there are differences in learning steps. The implementation Tri Hita Karana based Role playing creates a fun learning and increase students' activity in learning process because students can express their feeling as the character of the story. In this learning model, the students are divided into two big groups, namely observer and player, the observer group must observe their partner in doing their role in front of the class. Meanwhile, the player groups do their role based on the scenario prepared by the teacher. This learning process involves all students to be active so students feel happy and enjoy the learning. It makes the students learning outcome increase, especially Indonesian subject. The result of the present study is in line with (Tarigan's, 2016) opinion states that Role Playing can increase students' activity in learning process and the learning process focuses on the students' side (students center). In addition, the result of the present study is also in line with the opinion of (Ani et al., 2017) which states that Role Playing learning model can create students' activity in the learning process and interact in the learningteaching.

Apart from being in line with the opinions of several experts, the results of this study are supported by the results of the previous study conducted by (Mahaputra et al., 2016) state that the role playing learning model influences student learning outcomes in Indonesian subject because it can stimulate student creativity in the learning process, students are not only recipients of what the teacher gives but students are active in solving problems in the Indonesian content. Further research results from (Yuliani et al., 2018) show that the character education based role playing model influences the competence of students' social studies knowledge because all students are directly involved to build student interest in learning. Furthermore, a research result from (Adnyana et al., 2017) show that learning with Tat Twam Asi based Role Playing affects students' social studies knowledge competencies because it provides ample opportunities for students to construct their knowledge through role playing activities during the learning process which certainly make students happy in learning.

The implementation of Tri Hita Karana concept in the learning process aims to build a harmonious relationship with God, people, and the environment. By applying Tri Hita Karana, the learning process becomes more conducive because students can maintain their behavior and students become comfortable, as a result, the learning outcome becomes good. It is in line with (Putra's, 2019) opinion which states that the implementation of all Tri Hita Karana elements during the learning process, conducive learning and a sense of comfort will be created. Then, this opinion is also in line with (Narayani et al., 2019) state that Tri Hita Karana can make students protect the surrounding environment and create a conducive learning environment so that the learning process becomes comfortable. Furthermore, the opinion of (Yunita \& Tristiantari 2018) state that the existence of Tri Hita Karana can change students' behavior so that it can create g ood relationships in learning.

The success of learning outcomes by applying the Tri Hita Karana based Role Playing learning model is also supported by the results of the previous study conducted by Widnyana, et al. The result shows that the Tri Hita Karana based Role Playing learning model improves the competence of social studies knowledge. Furthermore, the results of a study conducted by (Basri, 2017) examine the implementation of the cooperative learning model (Role Playing) that improve the Indonesian learning outcomes of the fifth grade students. The results of this study indicate that the cooperative learning model type Role Playing can improve student learning outcomes in Indonesian both individually and classically

Based on the explanation above, the implementation of the Tri Hita Karana based Role Playing learning model can increase Indonesian learning outcomes. It is because students have high motivation and self-confidence in learning. Motivation and self-confidence arise because in learning students feel happy and the learning process 
is considered attractive to students by doing a role play in a story, and students can choose a role or character as their wishes. Students' motivation in learning is needed so that students have a strong intention to obtain maximum learning outcomes. Motivation is very important for students in learning because students will succeed in everything if they have high motivation (Sulistyorini \& Kristin, 2017). In addition, (Pratiwi \& Laksmiwati, 2016) state that children will succeed if they have the drive, intention, and confidence in themselves to get better results than before.

\section{Conclusion}

Based on the obtained analysis, it shows that the post-test mean score in Indonesian learning outcomes in the experimental group is greater than the control group, namely $(15.78>12.78)$, and based on the results of the hypothesis with the Independent Samples Test that the significant value is obtained in the sig column ( 2-tailed) is 0.000. This significant value is smaller than 0.05 so $\mathrm{H}_{0}$ is rejected and $\mathrm{H}_{1}$ is accepted. The results of the t-test analysis state that $\mathrm{H}_{1}$ is accepted which mean that there is an effect of the Tri Hita Karana based Role Playing learning model on the Indonesian learning outcomes of the fourth grade elementary school students in cluster XIII, Buleleng District, academic year 2019/2020.

\section{References}

Adiwiguna, I. W., Wiarta, I. W., \& Abadi, I. B. G. S. (2016). Model Pembelajaran Role Playing Berbasis Pendekatan Saintifik Berpengaruh Terhadap Penguasaan Kompetensi Pengetahuan IPS. E-Journal PGSD Unoversitas Pendidikan Ganesha, 4(1).

Adnyana, I. M. W., Putra, I. K. A., \& Suadnyana, I. N. (2017). Pengaruh Model Pembelajaran Role Playing Berbasis Tat Twam Asi Terhadap Penguasaan Kompetensi Pengetahuan IPS. International Journal of Elementary Education, 1(4).

Agung, A. A. G. (2016). Statistik Dasar Untuk Pendidikan. Yogyakarta: Deepublish.

Ani, N. K. K., Darsana, I. W., \& Asri, I. G. A. A. S. (2017). Pengaruh Model Pembelajaran Time Token Berbasis Tri Hita Karana Terhadap Hasil Belajar Ips Siswa Kelas V. Mimbar PGSD, 5(2).

Astami, N. M. W., Wiarta, I. W., \& Darsana, I. W. (2016). Penerapan Inkuiri Terbimbing Berbasis Tri Hita Karana Dapat Meningkatkan Sikap Sosial Dan Kompetensi Pengetahuan IPS. E-Journal PGSD Unoversitas Pendidikan Ganesha, 4(1).

Basri, H. (2017). Penerapan Model Pembelajaran Role Playing Untuk Meningkatkan Hasil Belajar Bahasa Indonesia Siswa Kelas V SDN 032 Kualu Kecamatan Tambang. Jurnal Pendidikan Dan Pengajaran, 1(1).

Chaer, Abdul dan Leonie Agustina. 2004. Sosiolinguistik Perkenalan Awal. Jakarta: Rineka Cipta.

Dewi, T. A. (2017). Efektivitas Model Role Playing Dalam Meningkatkan Kompetensi Mahasiswa Pada Mata Kuliah Manajemen Keuangan. Jurnal Promosi, 5(1).

Dibia, I. K., Arini, N. W., Garminah, N., \& Sumantri, M. (2017). Bahasa Indonesia. Singaraja: Undiksha Press.

Jaya, K. A. (2019). Membangun Mutu Pendidikan Karakter Siswa Melalui Implementasi Ajaran Tri Hita Karana. Jurnal Penjaminan Mutu, 5(1).

Krishna, A. (2018). Memaknai Kembali Hindu Dharma. Singaraja: Pusat Studi Veda \& Dharma.

Kristin, F. (2018). Meta-Analisis Pengaruh Model Pembelajaran Role Playing Terhadap Hasil Belajar IPS. Jurnal Refleksi Edukatika, 8(2).

Mahaputra, I. G. D., Suarni, N. K., \& Murda, I. N. (2016). Penerapan Metode Pembelajaran Role Playing Untuk Meningkatkan Hasil Belajar Bahasa Indonesia Siswa Kelas V Semester Ganjil SDN 4 Bungkulan Tahun Pelajaran 2016/2017. Mimbar PGSD, 4(3).

Mushfi, M. (2017). Model Interaksi Sosial Dalam Mengelaborasi Keterampilan Sosial. Jurnal Pendidikan, 4(2).

Narayani, N. N. W., Suwatra, I. I. W., \& Suarjana, I. M. (2019). Pengaruh Model Pembelajaran NHT Berbasis Tri Hita Karana Terhadap Karakter dan Hasil Belajar IPA. Jurnal Pendidikan Multikultural Indonesia, 2(1). 
Nurhayani, I. (2017). Pengaruh Penggunaan Metode Bercerita terhadap Kemampuan Menyimak Pada Mata Pelajaran Bahasa Indonesia. Jurnal Pendidikan Universitas Garut, 4(1).

Pradnyawathi, N. N. C., \& Agustika, G. N. S. (2019). Pengaruh Model Pakem Berbasis Tri Hita Karana Terhadap Keterampilan Menulis. International Journal of Elementary Education, 3(1).

Pratiwi, I. D., \& Laksmiwati, H. (2016). Kepercayaan Diri dan Kemandirian Belajar pada Siswa SMA Negeri "X." Jurnal Psikologi Teori Dan Terapan, 7(1).

Putra, I. G. N. P. A. L. (2019). Pengaruh Model SFAE Berorientasi Tri Hita Karana Terhadap Hasil Belajar IPA. Jurnal Ilmiah Sekolah Dasar, 3(2).

Rosdiana, Y. (2014). Bahasa dan Sastra Indonesia Di Sekolah Dasar. Jakarta: Universitas Terbuka.

Rosyidah, U. (2016). Pengaruh Model Pembelajaran Kooperatif Tipe Jigsaw Terhadap Hasil Belajar Matematika Siswa Kelas VIII SMP Negeri 6 Metro. Jurnal SAP, 1(2).

Sari, F. F. K. (2018). Peningkatan Hasil Belajar Siswa SD Pada Pembelajaran Tematik Melalui Penerapan Model Pembelajaran Role Playing. Jurnal Satya Widya, 34(1).

Sobry Sutikno, (2004). Model Pembelajaran Interaksi Sosial, PembelajaranEfektif dan Retorika. NTP Press. Mataram

Sulistyorini, E., \& Kristin, F. (2017). Penerapan Role Playing Untuk Meningkatkan Motivasi dan Hasil Belajar IPS Kelas V. Jurnal Pendidikan Dasar, 8(1).

Sumayasa, I. N., Marhaeni, A. A. I. N., \& Dantes, N. (2015). Pengaruh Implementasi Pendekatan Saintifik Terhadap Motivasi Belajar Dan Hasil Belajar Bahasa Indonesia Pada Siswa Kelas VI di Sekolah Dasar Se Gugus VI Kecamatan Abang, Karangasem. Jurnal Program Pascasarjana Universitas Pendidikan Ganesha, 5.

Santoso.2011. Pengertian Model Pembelajaran Student Facilitator and Explaining. http://raseko.blogspot.com/2011/05/pengertian-model-pembelajaranstudent.html. diakses 25 Februari 2012 .

Susanto, A. (2013). Teori Belajar \& Pembelajaran Di Sekolah Dasar. Jakarta: Prenadamedia Group.

Susanty, D. (2017). Model Pembelajaran Role Playing Pada Mata Pelajaran Bahasa Indonesia. Seminar Nasional.

Tarigan, A. (2016). Penerapan Model Pembelajaran Role Playing Untuk Meningkatkan Hasil Belajar IPS Siswa Kelas III SD Negeri 013 Lubuk Kembang Sari Kecamatan Ukui. Jurnal Primary, 5(3).

Wiana, Ketut. 2007. Tri Hita Karana Menurut Konsep Surabaya: PARAMITA.

Widnyana, I. G., Sujana, I. W., \& Putra, I. K. A. (2017). Pengaruh Model Pembelajaran Role Playing Berbasis Tri Hita Karana Terhadap Kompetensi Pengetahuan IPS Siswa Kelas IV SD Gugus Untung Surapati Kecamatan Denpasar Timur Tahun Pelajaran 2016/2017. Mimbar PGSD, 5(2).

Widyaningrum, H. K. (2015). Penggunaan Media Audio Untuk Meningkatkan Kemampuan Menyimak Dongeng Anak Pada Siswa Kelas IV Sekolah Dasar. Premiere Educandum, 5(2).

Widyaswari, I. G. A. A. (2019). Konsep Tri Hita Karana Pada Logo Yayasan Sharma Seni Museum Neka Di Ubud. Jurnal Nawala Visual, 1(1).

Yuliani, N. L. S., Wiyasa, I. K. N., \& Gading, N. N. (2018). Pengaruh Model Pembelajaran Kooperatif Tipe Role Playing Berbasis Pendidikan Karakter Terhadap Kompetensi Pengetahuan Ips Siswa Kelas V Sd Negeri Gugus Kapten Kompyang Sujana Denpasar Barat. Jurnal for Lesson and Learning Studies, 1(2).

Yunita, N. K. D., \& Tristiantari, N. K. D. (2018). Pengaruh Model Pembelajaran Kooperatif Tipe TGT Berbasis Kearifan Lokal Tri Hita Karana Terhadap Hasil Belajar. Jurnal Pendidikan Multikultural Indonesia, 1(2). 